\title{
AZ IPAR 4.0 ÉS AZ OKTATÁS KAPCSOLATA ÉS KÖLCSÖNHATÁSA
}

\section{THE RELATIONSHIP AND INTERACTION BETWEEN INDUSTRY 4.0 AND EDUCATION}

\author{
Beke Éva \\ Óbudai Egyetem, Biztonságtudományi Doktori Iskola, Budapest, Magyarország \\ beke.eva@bgk.uni-obuda.hu
}

\begin{abstract}
The effects and results of Industry 4.0 are ubiquitous: in mobile applications and laptops, in sensor-driven technologies, in communication capabilities, in intelligent robots, in smart offices and in cyberspace. In the future, the most sought after skills will not only be technology-related, but there will be a huge demand for creativity, emotional intelligence, critical thinking, and interpersonal skills.

Based on this knowledge, a whole new economic model and a change to the old system will be needed.
\end{abstract}

Keywords: competencies, Industry 4.0, industry expectations.

\section{Összefoglalás}

Az Ipar 4.0 hatásai és eredményei mindenhol jelen vannak: mobilalkalmazásokban és szuperszámítógépekben, szenzorvezérelt technológiákban, kommunikációs képességeikben, intelligens robotokban, okosirodákban és kibertérben. A jövő cégében a leginkább keresett készségek nemcsak a technológiával lesznek kapcsolatosak, hanem hatalmas kereslet lesz a kreativitás, az érzelmi intelligencia, a kritikus gondolkodás és az interperszonális készségekkel rendelkezők iránt.

Ezen ismeretek alapján egy teljesen új gazdasági modellre és a régi rendszer megváltoztatására lesz szükség

Kulcsszavak: készségek, Ipar 4.0, ipari elvárások.

\section{Bevezetés}

A negyedik ipari forradalom érkeztével mindennapossá váltak a robotikai alkalmazások, a felhőalapú számolás, a mesterséges intelligencia, a 3D-nyomtatás és a mindent behálózó szenzorok. Az Ipar 4.0 teremti meg az okos városok és mezőgazdaság alapjait, kiszámíthatóvá teszi a közlekedést, feltárja az eddig ismeretlen vagy veszélyes területeket drónok segítségével [1]. Kialakult egy új szektor: a kibertér, és ezzel együtt törékennyé vált a személyes adatok biztonsága. Felértékelődött a szellemi-intellektuális munkaerő, míg leértékelődött a fizikai erő az iparban. A jelenkori fogyasztói társadalom legfőbb jellemzői közül elsőként kell megemlítenünk, hogy ez - azaz a ne- gyedik - az első olyan ipari-technikai forradalom, amely a nagy tömegek jólétéhez, gazdasági és kulturális felemelkedéséhez vezethet [2]. A polgári demokrácia érvényesülése olyan alapvető emberi jogokban manifesztálódik, mint a választójog, a magasabb képzettség megszerzésének joga és lehetősége és a szociális juttatások. Míg korábban kizárólag a nyersanyagok birtoklása jelentette a gazdasági hatalmat, addig mára általánossá vált a szellemi tőke fölénye és annak felértékelődése, valamint a tanuláshoz-kutatáshoz kapcsolódó ipari előnyök megszerzése. Ehhez társult a határok nélküli áru-, pénz- és munkaerőmozgás, amely az egyes államok gazdasági szuverenitása helyett, mára alapvetően politikait jelent csupán, 
egy globálisan változó és alakuló gazdasági piac mellett [3].

Mint minden új rendszer, az Ipar 4.0 azt is tanította, hogy az emberek, rendszerek és tárgyak közötti kapcsolat bonyolultabb, dinamikusabb és egy valós idejű optimalizált hálózat lesz. Ennek köszönhetően az összeköttetés egy információs struktúrát hoz létre, és az ott gyüjtött adatokat tárolja, csoportosítja egy intelligens, felhőalapú rendszerben, amelyet aztán egy prediktív és automatizált döntéshozatalhoz felhasznál mesterséges intelligencia segítségével. A vállalatok, a gyártási egységek, a kutatási szektorok és a kormányok számos, különböző szinten megvalósítható biztonsági gyakorlatot vezetnek be, például a kiber- és a számítógépes támadások kivédésére, valamint a létesítmények és a személyzet védelmére.

Az ebből, az eredően egyedülálló paradigmából következően nemcsak fejlesztések és vívmányok, hanem zavarok is keletkezhetnek, ami azt jelenti, hogy egy nagy ígéret és nagy veszély kettősségében élünk [4].

\section{Az oktatás feladatai és kihívásai}

A változások elkerülhetetlenné váltak az oktatásban is. A hagyományos, formális oktatási rendszerek nem képesek többé választ adni az okos városok és a kapcsolódó társadalmak legfontosabb elvárásaira. A jelen oktatási rendszerek többsége a 20. századi rendszeren alapul, és figyelmen kí- vül hagyja a 21. századi ipari és munkatrendeket és elvárásokat [5]. Új kompetenciák oktatása, új oktatási modellek és struktúrák bevezetése elkerülhetetlenné vált. Ennek eredményeként a ma használatos készségek és kompetenciák 35\%-a szintén cserélődik, mert ezeknek összhangban kell lennie a mindenkori munkaerő piaci követelményekkel ahhoz, hogy müködő, hatékony gazdaságról beszélhessünk.

A legmodernebb robotikai újítások, a vezető nélküli járművek, az infokommunikációs eszközök és hálózatok jelenléte, a közlekedés megújulása olyan versenyhelyzetet teremt, amelyben a tudásmegszerzésre irányuló törekvéseket is újra kell tervezni. Tanulókat és hallgatókat nem lehet többé a kizárólag lineáristudás-alapú oktatással a jövőre felkészíteni, még kevésbé arra, hogy a robotokkal versenyezzenek [6]. Ezért olyan készségek és kompetenciák előtérbe helyezése és fejlesztése válik szükségessé, amelyre a robotok még nem képesek. Ezek közül a legfontosabbak a kreativitás, a kritikus gondolkodás, valamint az alternatív problémamegoldások és -mérlegelések kérdésköre. A kutatásomban megkeresett vállalatoktól egyebek mellett fontosnak tartottam megkérdezni, hogy milyen javaslataik lennének, hogy még hatékonyabb legyen az ipari-akadémiai oldal együttműködése, valamint arról is, hogy milyen javaslatokat fogalmaznak meg az oktatási struktúra átalakítására. A másik fontos téma az ipar által elvárt és hasznosítható készségek kérdésköre volt. A kérdőíves, feltáró kutatással az a célom,

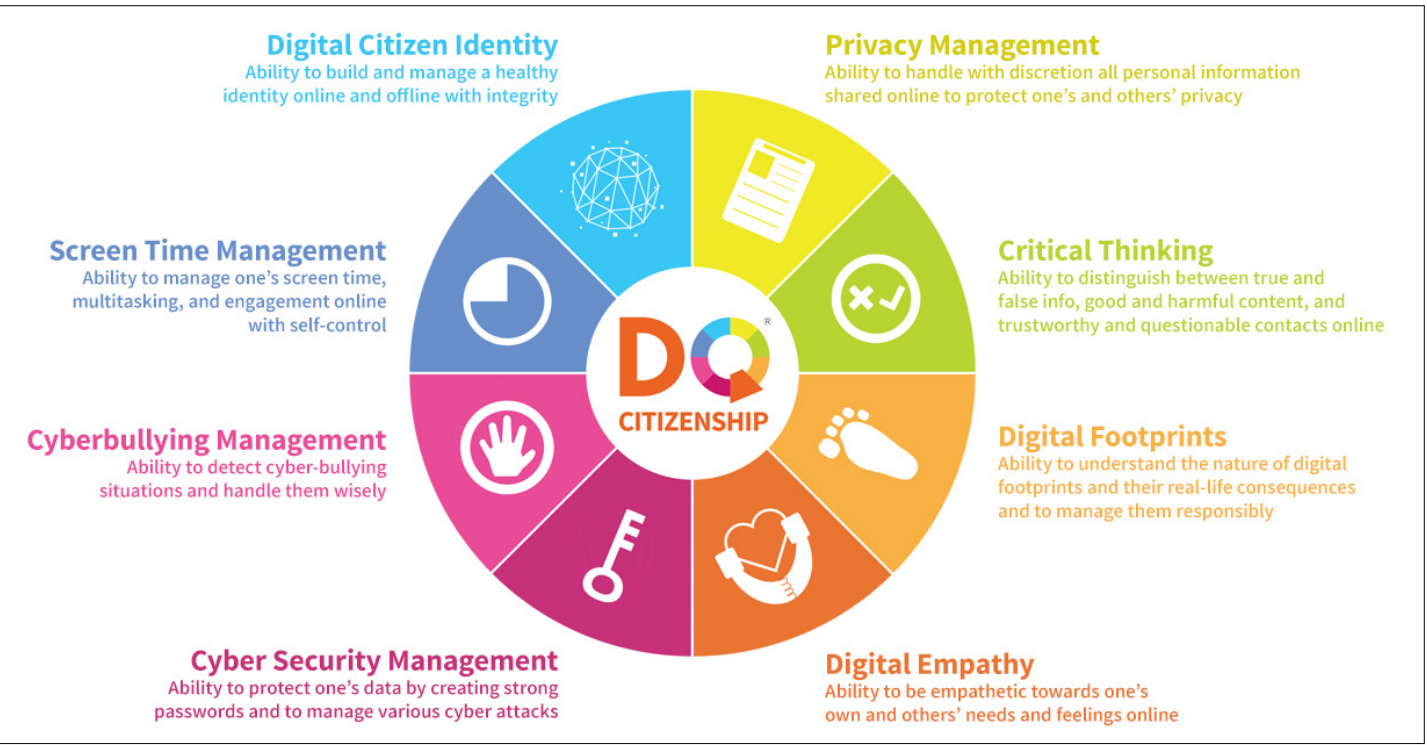

1. ábra. Digitális intelligencia az Oktatás 4.0. korában (World Economic Forum, február, 2020.) 
hogy viszonylag kis elemszámú minta mellett árnyaltabb, mélyebb ismereteket gyüjtsek össze a megkérdezettek véleménye alapján [7]. A résztvevők munkahelyi profiljukat tekintve két csoportra oszthatók: az egyikbe azok tartoznak, akik a cégeiket az Ipar 4.0 jegyében fejlesztik a robotizáció, innováció, a folyamatszervezés modernizálása vagy a leginnovatívabb gépsorok beszerzésével, míg a másik csoport a biztosításhoz kapcsolódik: egyfelől informatikai részről a biztosítási ügyletek ügyviteli és értékesítési folyamatainak támogatására szakosodott vállalkozás, valamint egy biztosítótársaság alkotja. Az első csoport a ma Magyarországon leghúzóbb és befolyását tekintve a legtöbb munkaerőt alkalmazó ipari szektorhoz, a gépiparhoz köthető, akár alkatrészek gyártása, akár a tervezés területéhez kapcsolódóan [8]. A megkérdezettek között 4 nemzetközi cég, míg két közepes méretű, magyar vállalkozás szerepelt.

$\mathrm{Az}$ open-ended question-methodot használtam fel a válaszok kiértékelésére. A válaszadók közül öt „több gyakorlati képzést” vezetne be a felsőoktatási intézményekben, míg három javasolta „céges szakemberek bevonását az oktatásba”. Ketten jelezték, hogy a kikerülő hallgatóknál hiányzik a kommunikációs és prezentációs készség, míg egy-egy esetben került szóba, hogy az „oktatókat kellene kihelyezett projektmunkára” meghívni, bevezetni a „müszaki-matematikai képzést minden területen”, az „elavult képzési tervek” helyett „közös projektmunkákat” és “esettanulmányi versenyeket” hirdetni.

\section{3. Új vállalati-szervezeti modellek}

Nemcsak az akadémiai oldalnak és a kormányoknak, hanem természetesen a vállalatoknak is rugalmasan kell alkalmazkodniuk a 21. századi kihívásokhoz. Gyártási és technológiai szinten éppúgy, mint humán erőforrások tekintetében. A vállalatoknak át kell képezniük a munkavállalóikat, új munka- és szervezeti modelleket kell elfogadniuk, az Ipar 4.0 vívmányait szem előtt tartva, új stratégiai munkaerő-tervezéssel kell foglalkozniuk [9].

Az Ipar 4.0 új típusú kölcsönhatásokat eredményez az emberek és a gépek között - olyanokat, amelyek jelentős hatással lesznek a munka és a szervezeti struktúrák természetére. A gyártási ütemezések növekvő változékonyságának kielégítése érdekében a vállalatoknak olyan új munkamodelleket kell figyelembe venniük, amelyek rugalmas irodai időbeosztást tartalmaznak. Annak érdekében, hogy sikeres legyen az Ipar 4.0, a vállalatoknak új megközelítéseket kell figyelem- be venniük a munkaerő-toborzás és -megtartás területein is [10]. Képességekre és kompetenciákra összpontosító toborzás szükséges, nem pedig fokozatokra és titulusokra épített képesítésekre. Mivel a munkavállalók az alapképzésükhöz nem kapcsolódó feladatok szélesebb körén fognak dolgozni, a toborzóknak gyakran a formális képzés adta tudáson túli készségeket is figyelembe kell venniük, hogy olyan munkaerőt találjanak, akik az adott feladatokhoz szükséges készségekkel rendelkeznek. „Radikálisan eltérő gondolkodásra és platformokra van szükségünk, hogy a képesítések helyett inkább a képességekre összpontosítsunk - az új munkaerőpiacon...” - jegyzi meg Alexander Spermann.

A fenti kutatásokat is figyelembe véve arról is megkérdeztem a cégeket, hogy ők milyen készségek alapján választanak munkaerőt. A válaszadók közül ketten nagyon specifikusan a „gépiparhoz kapcsolódó tudás” alapján, míg másik kettő a „hatékony problémamegoldás” szempontját figyelembe véve választ munkaerőt [11]. A megkérdezettek fele, azaz három cég vallotta, hogy a “csapatmunka”, “kreativitás” és a „változás-menedzsmentkezelés” befolyásolja döntően a választásukat. Ketten érezték fontosnak, hogy a jelentkező rendelkezzen a munkához szükséges lelkesültséggel („drive”), míg egy-egy megkérdezett jelezte, hogy a „lelki kiegyensúlyozottság”, az „alkalmazkodókészség” és a „kritikai gondolkodásmód” játszik abban szerepet, hogy ki lesz a sikeres jelölt. Figyelembe véve a generációk közötti különbségeket, egy válaszadó fontosnak ítélte meg a „vegyes életkort”, míg egy másik ugyanilyen megfontolások alapján az „alkalmazkodóképességet” [12].

\section{Következtetések}

A megváltozott piaci elvárások közepette egyre fontosabbá válik, hogy mind a munkáltatók, mind a piac, illetve a munkahelyek felismerjék az egyén saját legjobb képességeit, és az egységes, szigorúan kötött tanulási folyamatok és rangsorok helyett biztosítsák a nonlineáris oktatási formákat. A régebben megszerzett és fontosnak számító kompetenciákat nem elvetve, hanem azokat beépítve egy új szisztéma bevezetése várható, amely ezeket a régi gyakorlatokat felhasználva újakat tanít, alkalmazkodva a mindenkori, gyorsan változó piaci normatívákhoz. Számos kutatás tárgya a digitális bennszülöttek és a digitális bevándorlók közötti különbségek feltárása. Mára egyre nyilvánvalóbbá válik, hogy a digitális 
bennszülöttek jó része tudja, hogy hogyan használja a legújabb technológiákat, de nem tudják, hogy ezek hogyan támogathatják a tanulási folyamataikat [13]. Távolról sem rendelkeznek annyi tudással és gyakorlattal, mint azt első körben feltételezték, így a legújabb tendenciák igyekeznek a kombinálni és utat engedni a formális és nem formális tanulásnak, e kettő között olyan átmenetet teremteni, amely jövő generációs technikai felkészültséggel rendelkező, ugyanakkor sajátosan emberi készségekkel is ellátott polgárokat neveljen [14].

\section{Köszönetnyilvánítás}

$\mathrm{Az}$ Innovációs és Technológiai Minisztérium ÚNKP-19-1415/38 kódszámú Új Nemzeti Kiválóság Programjának szakmai támogatásával készült.

\section{Szakirodalmi hivatkozások}

[1] Beke É.: Industry 4.0 and its risks in the state administration, corporate and medical sectors. National security review: periodical of the military national security service, 1. (2018) 98-110.

[2] Beke É., Kolnhofer-Derecskei A.: Talent management at Óbuda University focusing on teachers' and students' roles. In: Konferenciaközlemény (FIKUSZ) 2018.

[3] Erol Selim et al: Tangible Industry 4.0: a scenario-based approach to learning for the future of production. Procedia CIRP, 54. (2016) 13-18. https://doi.org/10.1016/j.prcir.2016.05.102

[4] Kopátsy S.: Új Közgazdaságtan. A minöség társadalma. Akadémiai Kiadó, Budapest, 2011.

[5] Dobbins M., Knill C: Higher Education Policies in Central and Eastern Europe: Convergence toward a Common Model. Governance, 22/3. (2009) 397-430.
[6] Benesova A., Tupa J.: Requirements for Education and Qualification of People in Indusrty 4.0. Procedia Manufacturing, 11. (2017) 2195-2200. https://doi.org/10.1016/j.promfg.2017.07.366

[7] Hatum A.: Next-generation talent management. Palgrave MacMillan Publication, Basingstoke, United Kingdom, 2016.

[8] Hecklau F. et al: Requirements for Education and Qualification of People in Indusrty 4.0 - Holistic approach for human resource management in Indusrty 4.0. Procedia CIRP, 54. (2016) 1-6.

[9] Jakab L., Sallai Gy., Kovács K.: A smart city megoldások technológiai háttere és fenntartható komplex modellje. Magyar tudomány, 8. (2017) https://doi.org/10.1556/2065.179.2018.9.4

[10] Kiss D.: A szellemi tőke szerepe a posztindusztriális társadalomban. Journal of Economy and Society, 2-3. (2013) 16-18.

[11] Hartmann E., Bovenschulte M.: Skills Needs Analysis for Industry 4.0 based on roadmaps for smart systems. In: SKOLKOVO Moscow School of Management \& International Labour Organization Global Workshop Proceedings, 2013.

[12] Mulder M.: Conception of professional competence. In: Billett S., Harteis C., Gruber H. (Eds.): International Handbook of Research in Professional and Practice-based Learning. Dordrecht, Springer, 2014. 107-137.

[13] Schwab K.: The Fourth Industrial Revolution. 1. ed. Crown Business, New York, USA, 2018.

[14] Varga J.: A készségek és az oktatás követelményrendszere a tudásalapú társadalomban. Magyar Tudomány, 1. 2018.

https://doi.org/10.1556/2065.179.2018.1.8 